\title{
Grammatical Intricacy in EFL Textbooks
}

\author{
Vinh To \\ University of Tasmania \\ School of Education, Locked Bag 1307 \\ Launceston, Tasmania 7248, Australia \\ E-mail: Vinh.To@utas.edu.au
}

Received: October 18, 2017 Accepted: October 30, $2017 \quad$ Published: October 31, 2017

doi:10.5296/ijele.v5i2.12087 URL: https://doi.org/10.5296/ijele.v5i2.12087

\begin{abstract}
Grammatical intricacy is an important concept in charactering complexity of language (Halliday, 2008). However, this concept has not yet been fully investigated in the teaching and learning of English as a foreign language (TEFL), particular in English as a foreign language (EFL) textbooks in higher education. This paper aims to examine grammatical intricacy across textbook levels in a book series used in tertiary education in the Vietnamese context. This is part of a larger research project looking at linguistic complexity of English textbooks in the TEFL setting. The research employed Systemic Functional Linguistics (SFL) as the main theoretical framework and Halliday's method as a measure of grammatical intricacy to look at how this language feature was used in reading comprehension texts in four textbooks at different levels including elementary, pre-intermediate, inter-mediate and upper-intermediate. The findings revealed that grammatical intricacy increased in accordance with the book levels. Particularly, the mean scores of grammatical intricacy showed a gradual increase from the elementary to the intermediate book level; though they were not different significantly and the upper-intermediate textbook did not show the topmost grammatical complexity. These findings suggest that the use of grammatical intricacy in the investigated textbooks was appropriate for EFL learners across levels; however, the use of other linguistic features such as lexical density and nominalisation may potentially impact the use of simple clauses in the textbooks at a higher level. Thus, further investigations are recommended to fully explore the complexity of textbook language.
\end{abstract}

Keywords: grammatical intricacy, English textbooks, Systemic Functional Linguistics 


\section{Introduction}

Linguistic complexity has been an interesting topic for educational linguistics research for many decades. While this concept has been extensively explored (see Benedikt \& Bernd, 2009, 2012; Dahl, 2008; Fred, 2009; Hendrikse \& Van Zweel, 2010; Juola, 2008; Kuiken \& Vedder, 2007; Miestamo, 2009; Ortega, 2003), there is no general consensus on the measures of it as different linguistic theories result in different perspectives on the complexity of human language (To, Fan \& Le, 2015). From the traditional grammar approach, linguistic complexity involves the concept of markedness which leads to the notion of formal complexity. "The marked is structurally more complex and the unmarked more simple" (Givón, 1995, p. 25). As Givón (1995) commented, "The main, declarative, affirmative, active clauses have been tacitly assumed, in grammatical description ever since the Greeks, to be the privileged, unmarked clause type" (p. 32). Therefore, they are considered simple, while the more complex forms of grammar involve the use of subordination, interrogatives, imperative, negatives and passives. Chomsky (1965) offers a different perspective on linguistic complexity. He proposed the concepts of surface and deep structures and noted that linguistic complexity is concerned with the deep structures due to their different interpretations. However, this complexity also involves syntactic ambiguity in the surface structures in writing (To et al., 2015). Halliday (1985a), the father of functional grammar or SFL theory, states that complexity of language typically deals with grammatical intricacy, lexical density, nominalisation, grammatical metaphor and thematic structure (Halliday, 1985a, 1985b, 1994, 2008; Halliday and Matthiessen, 2004). Within the scope of this paper, it looks at one language feature that characterises complexity of language from a Hallidayan perspective, namely grammatical intricacy. The following theoretical background section will describe this theory and the chosen concept in greater detail.

\section{Theoretical Background}

\subsection{Systemic Functional Linguistics}

SFL is a linguistic theory that views language as a social semiotic system and a meaning-making resource (Halliday \& Matthiessen, 2004). This means it sees how people use language to construe and create meaning to fulfil their communicative purposes in social contexts. In SFL, language is realised in four levels of abstraction known as four strata of language: grapho-phonology, lexico-grammar, discourse semantic, and context (Halliday \& Matthiessen, 2004). Phonetics and phonology belong to the expression plane, which are the most basic linguistic resources for making meaning (Halliday \& Matthiessen, 2004). At the lexico-grammar level, meaning is realised by means of wording through three levels of rank: word, group and clause (Halliday \& Matthiessen, 2004). The discourse semantic level involves three metafunctions, namely the ideational meaning, interpersonal meaning and textual meaning. The ideational meaning represents human experience about the world; the interpersonal meaning enacts the interactions between the writer/speaker and the reader/listener; and the textual meaning is concerned with the text organisation (Martin \& Rose, 2003). The ideational meaning, which includes experiential and logical meanings, is 
realised by lexical and grammatical choices such as lexical items, transitivity systems, and the logico-semantic types. The interpersonal meaning is realised by mood, modality and evaluative language. Finally, the textual meaning is realised by thematic and information structure (Halliday \& Matthiessen, 2004), and the text periodicity (Martin and Rose, 2003). At the level of context, genre and register are realised. Genre is "a staged, goal-oriented, purposeful activity in which speakers engage as members of our culture" (Martin, 2001, p.155). This means genre is concerned with the context of culture. Genre is realised through register which is "the immediate situational context in which the text was produced" (Eggins, 1994, p.26). In other words, register refers to the context of situation. Three register variables are field, tenor and mode which determine the ideational meaning, interpersonal meaning and textual meaning respectively at the discourse semantic level. This present research looks at the language of textbooks at the lexico-grammar level and this involves the ideational meaning, particularly the logical meaning or metafunction which is realized by the logico-semantic types to investigate how different types of clauses are used to characterize the grammatical complexity of written language.

\subsection{Grammatical Intricacy}

Grammatical intricacy refers to how simple clauses in a clause complex are connected by means of logico-semantic types at the clausal level. As such, grammatical intricacy help construe the logical metafunction of language (Halliday, 2008). Grammatical intricacy refers to how lexical items are scattered in strings of clauses in clause complex; as a result, it is measured by the proportion of ranking clauses per total number of clause complexes (Halliday, 2008). In other words, this is calculated by the proportion of the number of ranking clauses including paratactic and hypotactic clauses (length) and the number of clause complexes in a text (Halliday, 2008). As far as the measure of grammatical intricacy is concerned, if there are a number of simple ranking clauses in a clause complex, giving the high score of grammatical intricacy, the text is more intricate. The notational conventions of SFL are provided in Table 1 to understand the analysis of examples in this study.

Table 1. SFL notational conventions and meanings

\begin{tabular}{|l|l|}
\hline SFL notational conventions & \multicolumn{1}{c|}{ Meanings } \\
\hline\|\| & clause complex boundary \\
\hline$\|$ & ranking clause boundary \\
\hline$[[\quad]]$ & embedded clause boundary \\
\hline$\alpha, \beta, \gamma, \ldots$ & hypotactic structure \\
\hline $1,2,3, \ldots$ & paratactic structure \\
\hline$=$ & expansion: elaboration \\
\hline+ & expansion: extension \\
\hline $\mathrm{x}$ & expansion: enhancement \\
\hline “ & projection: locution \\
\hline ' & projection: idea \\
\hline
\end{tabular}


Example 1: $\|(\alpha)$ We have also learned $\|(' \beta+\beta)$ that while a person is asleep, $\|(\beta \alpha)$ the brain is very active.||| (Text E3)

In Example 1, there are three ranking clauses connected by means of hypotactic projection and hypotactic extension in the clause complex, giving the grammatical intricacy score at 3.

\subsection{Grammatical Intricacy and the Logical Metafunction}

Grammatical intricacy deals with the logical metafunction. It is a way of managing complexity and construes the ideational metafunction of language. Halliday (2008) states that

The intricacy that is characteristic of spoken language is a different manner of deploying grammatical energy, exploiting the "logical" way of looking at phenomena (note that "logical" here always refers to grammatical logic, not to formal logic — which is a designed extension of it). The principle of setting up a logical-semantic relationship between two figures is extended recursively, so that it can be extended to construe complex sequences of figures that are related systemically: in grammatical terms, a "nexus" can initiate a "complex" of any length. [...] It is a powerful resource; it suits the "choreographic" spoken language, which unfold in time and builds up its own discursive momentum. (p.163)

The relationship between clauses in clause complex is determined by taxis and logico-semantics systems. Firstly, taxis refers to two degrees of interdependency between clauses including parataxis (equal status) and hypotaxis (unequal status) (Halliday \& Matthiessen, 2004). They are independent and dependent clauses in the traditional terms respectively. Parataxis is "the relation between two like elements of equal status, one initiating and the other continuing" (Halliday \& Matthiessen, 2004, pp. 374-375). Hypotaxis is "the relation between a dependent element and its dominant, the element on which it is dependent" (Halliday \& Matthiessen, 2004, p. 374). Hypotactic structures are often presented by Greek letters (e.g. $\alpha, \beta$ ), while paratactic structure by numerical notation (e.g., 1, 2). Secondly, a clause complex can be formed through a range of different logico-semantic relations which "holds between a primary and a secondary member of a clause nexus" (Halliday \& Matthiessen, 2004, p. 377). Two kinds of logico-semantic relations are expansion and projection. Expansion is the secondary clause expanding the primary clause, by (a) elaborating it, (b) extending it or (c) enhancing it. Projection is the secondary clause projected through the primary clause, which instates it as (a) a locution or (b) an idea (Halliday \& Matthiessen, 2004, p.373), as summarised in Figure 1. 


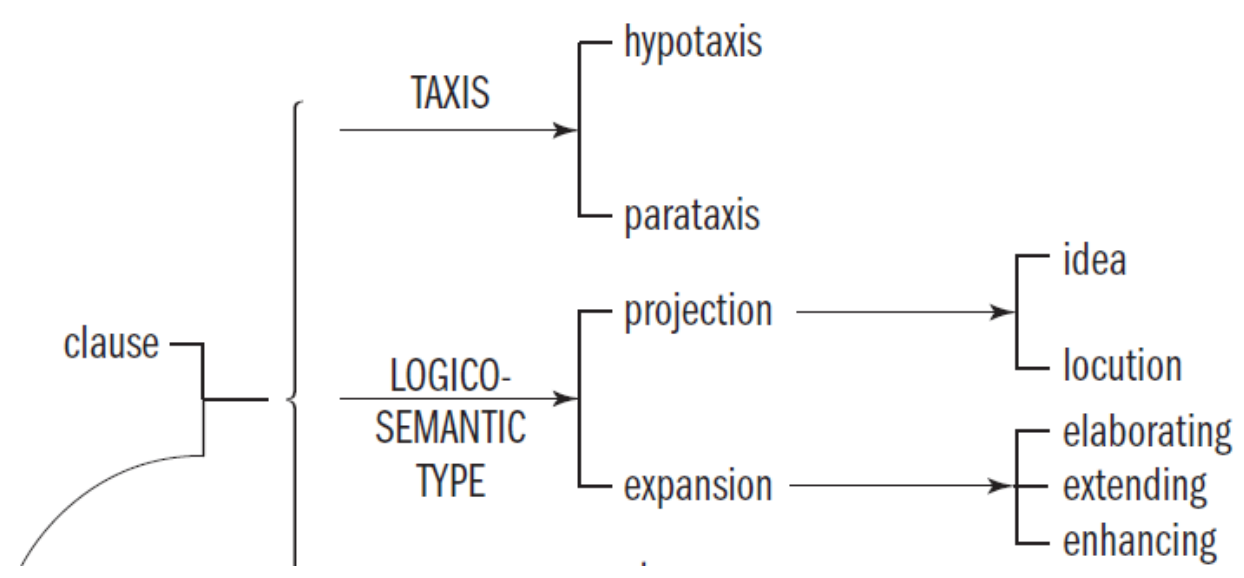

Figure 1. Types of relationship between clauses in the clause complex (Adapted from Halliday \& Matthiessen, 2004, p. 373)

For instance, in Example 2, two ranking clauses "Scientists think" and "that every dolphin has its own whistle" are connected by hypotactic relationship and logico-semantic relations of idea projection in the clause complex, giving the intricacy score of 2.

Example 2: ||| ( $\alpha$ ) Scientists think | (' $\beta$ ) that every dolphin has its own whistle ||| (Text E2).

\subsection{Paratactic Clauses, Hypotactic Clauses and Embedded Clauses}

The distinction between paratactic clauses, hypotactic clauses and embedded clause are crucial to grammatical intricacy analysis according to Halliday's method. Ranking clauses is the term used to indicate paratactic clauses (independent clauses) and hypotactic clauses (dependent clauses) (See Halliday \& Matthiessen, 2004; Lukin, 2013; Butt, Rhondda, Sue, \& Collin, 1997; Thompson, 1996; Humphrey, Droga \& Feez, 2012), while embedded clauses is another term used to indicate non-ranking clauses. Detailed explanations and examples of these types of clauses are provided in the following sections.

\subsubsection{Paratactic Clauses}

Paratactic clauses are finite clauses which can be a simple clause itself or a number of simple clauses joined by coordinating conjunctions such as and, so, therefore, however, etc. which are of equal status (Thompson, 1996).

Example 3:

||| People dressed in costumes, || wore colourful masks, || ate, || drank, and || danced all night on the Tuesday before the start of Lent. ||| (Anderson, 2003a, p.122)

The first clause is independent, so the other clauses joined by and are also independent. Overall, there are 5 ranking clauses in Example 3. 


\subsubsection{Hypotactic Clauses}

Hypotactic clauses are finite or non-finite clauses which have unequal relations with the paratactic clauses in the logical dependency (Thompson, 1996). Finite hypotactic clauses are formed by the use of projection (indirect speech) and subordinating conjunctions.

- Projection

Example 4: ||| Dream researchers think that || people in our dreams can tell us something about ourselves.||| (Anderson, 2003a, p.157)

The first clause is independent while the second which is the projection (indirect speech) is dependent.

- Subordinating conjunctions

Example 5: ||| If the person in the dream was yelling, || for example, maybe you are angry. ||| (Anderson, 2003a, p.157)

Example 6: |||When we read books, magazines, and newspapers, || we rarely stop and think about the paper used to make it. ||| (Anderson, 2003a, p.12)

The three dependent clauses in Examples 4, 5 and 6 are finite and connected to the main clauses by subordinating conjunctions if and when.

Non-finite clauses can be joined with the main clauses by subordinating conjunctions as can be seen in Example 7; or clauses of purpose as seen in the first clause of Examples 8 and 9; or serve as hypotactic elaborations in Example 10.

Example 7: |||By learning more about our dreams, || we may learn more about ourselves. ||| (Anderson, 2003a, p.157)

Example 8: |||In order to impress King Louis XIV, || the officers paraded in front of him || wearing brightly colored silk handkerchiefs around their necks. ||| (Anderson, 2003a, p.157)

Example 9: |||To be successful, || and to enjoy your experience abroad, || you must be flexible, open-minded, and both eager and willing to learn new ways of doing things. III (Anderson, 2003d, p.4)

Example 10: |||Astronauts can be exposed to intense radiation from the sun and other galactic bodies, || leaving them at risk of cancer. ||| (Anderson, 2003c, p.111)

Non-finite clauses can be also be non-defining relative clauses as seen in Examples 11 and 12. Three clauses in bold in Examples 11 and 12 are independent non-defining relative clauses which are proceeded by a comma.

Example 11: || The only Asian country to adopt it at that time, though, was the Philippines, || which the Spanish invaded in the sixteenth century. ||| (Anderson, 2003b, p.3)

Example 12: |||Karaoke, || which ranked fourth, || was more popular than watching videos, || which came sixth. ||| (Anderson, 2003b, p.83)

\subsubsection{Embedded Clauses}

Bloor and Bloor (1995) defines that embedded clause is "the clause which is inside another 
clause" (p.153). Butt et al. (1997) explains that "Embedded clause do not have the same status, i.e. are not at the same rank, as independent or dependent clauses. They are doing service within a group, which is why they are described as embedded." (p.114). Embedded clauses are also called rankshifted or downranked clauses (Halliday, 1985a; Bloor \& Bloor, 1995). Based on the explanations of embedded clauses of previous linguists (Halliday, 1985a, 1994; Halliday \& Matthiessien, 2004, 2014; Lukin, 2013; Butt et el., 1997; Thompson, 1996; Humphrey, Droga \& Feez., 2012), embedded clauses in this research are described below.

- $\quad$ An Embedded clause is a nominal group itself.

Example 13: [[What I like most about Australia]] is its climate.

- An Embedded clause is a nominal group of a defining relative clause.

Example 14: Numerologists believe that people with this number are peaceful, affectionate people [[who can also be very reserved]]. (Anderson, 2003b, p.57)

- An Embedded clause is nominal group of a prepositional phrase.

Example 15: It is an example of [[how the structure of language is significant in understanding how the written language works]]. (Thompson, 1997, p.179)

- An Embedded clause is a non-finite clause.

Example 16: [[Escalating classroom violence]] has also motivated some parents [[to remove their children from school]]. (Anderson, 2003c, p.135)

- An Embedded clause is an adverbial group.

Example 17: He walked so fast [[that I couldn't keep up him]].

It is important to note that embedded clauses can be finite (see Example 18) or non-finite (see Example 19).

Example 18: Of course, [[where you live]] and [[how long you live]] will influence [[how much a million dollars can buy]]. (Anderson, 2003c, p.64)

Example 19: For the chronic procrastinator, often the only way to solve this problem is [[to quick school]]. (Anderson, 2003c, p.7)

\section{Methodology}

\subsection{Text and Textbooks Selection}

This study examined grammatical intricacy of four international textbooks at four different levels from low to high, named Active Skills for Reading (Anderson, 2003a, 2003b, 2003c, 2003d). The chosen textbooks have been widely used as the main English reading textbooks in the language education programs in universities and language centres in Vietnam for a number of years. The book series includes four books 1, 2, 3, and 4 and are classified into four levels: elementary, pre-intermediate, intermediate and upper-intermediate respectively. Each book level consists of 32 reading passages covering various genres and belongs to both science and non-science domains.

With the purpose of investigating grammatical complexity in written texts, the research only focused on reading comprehension texts in the selected textbooks. The research focused on academic genres and excluded conversations or interviews which are concerned with spoken mode. Based on these criteria, twenty four texts in four books were chosen with six texts per 
book. The chosen texts were classified into four groups: Elementary $(n=6)$, Pre-intermediate $(n=6)$, Intermediate $(n=6)$ and Upper intermediate $(n=6)$. For the purpose of analysis, six texts at each level were coded as described in Table 2.

Table 2. Coded texts

\begin{tabular}{|c|c|c|c|c|}
\hline Text & $\begin{array}{c}\text { Book 1 } \\
\text { Elementary }\end{array}$ & $\begin{array}{c}\text { Book 2 } \\
\text { Pre-intermediate }\end{array}$ & $\begin{array}{c}\text { Book 3 } \\
\text { Intermediate }\end{array}$ & $\begin{array}{c}\text { Book 4 } \\
\text { Upper-intermediate }\end{array}$ \\
\hline 1 & E1 & P1 & I1 & U1 \\
\hline 2 & E2 & P2 & I2 & U2 \\
\hline 3 & E3 & P3 & I3 & U3 \\
\hline 4 & E4 & P4 & I4 & U4 \\
\hline 5 & E5 & P5 & I5 & U5 \\
\hline 6 & E6 & P6 & I6 & U6 \\
\hline
\end{tabular}

\subsection{Method of Analysis}

Grammatical intricacy is measured as the number of ranking clauses in the clause complex (Halliday, 2008).

$$
\text { Grammatical intricacy }=\quad \frac{\text { total number of ranking clauses }}{\text { total number of clause complexes }}
$$

As far as the formula of calculating grammatical intricacy is concerned, "the intricacy of grammar is captured in terms of how many clauses join together to form a clause complex, and the higher the index is, the more intricate the text." (Castello, 2008, p.97)

\subsection{Procedure of Grammatical Intricacy Analysis}

Grammatical intricacy was determined based on the following steps. First, ranking clauses which are non-embedded including hypotactic and paratactic clauses were counted based on the classification of parataxis, hypotaxis and embedded clauses discussed in theoretical background section. To summarise briefly, parataxis includes 'and/or' type complexes, 'i.e. /e.g. -type complexes, 'then/so/but' - type complexes and direct speech complexes. Hypotaxis includes 'besides/instead of' - type complexes, 'non-defining relative' complexes, 'when/because/if' -type complexes and indirect speech complexes (Halliday, 1985b, p.83). Embedded clauses were not counted in calculating grammatical intricacy. Second, total of clause complexes were determined. As for clause complex, it is defined as "a language 
structure that consists of one clause working by itself, or a group of clauses that work together through some kind of logical relationship" (Butt et al., 2000, p.30). In other words, the clause complex determined in this study coincides with the orthographic unit of sentence ending with full stops. The ratio of ranking clauses per clause complexes is the grammatical intricacy index.

\subsection{Sample Grammatical Intricacy Analysis}

To understand the sample intricacy analysis, please look at the notational conventions in SFL provided previously.

Box 1. Sample analysis of grammatical intricacy

|| Marriage is an ancient religious and legal practice [[celebrated around the world]] II. (x $\beta$ ) Although the reasons that people marry are similar in many places, $\|(\alpha)$ wedding customs vary from country to country $\|$.

I|| In many countries, it is customary for the bride to wear a white dress as symbol of purity. ||| In traditional Japanese wedding ceremonies, the bride wears a white kimono. \|\| The tradition of wearing a special white dress only for the wedding ceremony started around 150 years ago.||| Before that, most women could not afford to buy a dress that they would only wear once. ||| (1) Now, bridal dresses can be bought in a variety of styles and fabries, $\|(+2)$ and many brides have their dress specially made \|\| .

As can be seen in Box 1, there are 9 ranking clauses and 7 clause complexes, giving the grammatical intricacy value of 1.29 for this extract.

\section{Findings and Discussion}

The raw data on grammatical intricacy including the number of ranking clauses, clause complexes and grammatical intricacy score of each text was displayed in the Appendix. As demonstrated in Table 3, data is presented as mean \pm standard deviation plus minimum and maximum scores. The grammatical intricacy mean score increased from the Elementary (1.58 $\pm .30)$ to Pre-intermediate $(1.76 \pm .41)$ to Intermediate $(1.80 \pm .28)$ and maintained the relatively similar figure at the Upper intermediate level $(1.73 \pm .28)$. These figures indicate that on average, there were 1.58 ranking clauses per clause complex in the Elementary book. The number of ranking clauses per clause complex in the other three levels of book was 1.76, 1.80 and 1.73 from low to high respectively. A one-way ANOVA test was conducted to determine if grammatical intricacy formula was different for the four levels of books. Although grammatical intricacy increased in accordance with the book levels, there were no statistically significant differences in grammatical intricacy scores among different levels of textbooks as assessed by one-way ANOVA test $(\mathrm{F}(3,20)=.548, \mathrm{p}=0.655>0.05)$ as seen in Table 4. 
Table 3. Descriptive statistics on grammatical intricacy across levels

\begin{tabular}{|l|l|l|l|l|l|}
\hline Levels of textbook & $\mathbf{N}$ & Mean & Std. Deviation & Minimum & Maximum \\
\hline Elementary & 6 & 1.58 & .30 & 1.20 & 1.88 \\
\hline Pre-intermediate & 6 & 1.76 & .41 & 1.53 & 2.58 \\
\hline Intermediate & 6 & 1.80 & .28 & 1.31 & 2.07 \\
\hline Upper-intermediate & 6 & 1.73 & .28 & 1.29 & 2.08 \\
\hline
\end{tabular}

Table 4. Comparisons of grammatical intricacy between levels

\begin{tabular}{|l|l|l|l|l|l|}
\hline Grammatical intricacy & $\begin{array}{l}\text { Sum of } \\
\text { squares }\end{array}$ & df & Mean Square & F & Sig. \\
\hline Between groups & .169 & 3 & .056 & .548 & .655 \\
\hline Within groups & 2.060 & 20 & .103 & & \\
\hline Total & 2.229 & 23 & & & \\
\hline
\end{tabular}

The finding shows that although the intricacy values displayed the increasing pattern from 1.58 ranking clauses per clause complex in Book 1 to 1.8 ranking clauses per clause complex in Book 3, the figures were not statistically significantly different. It is also worth noting that there were no differences in grammatical intricacy scores in Book 2 set for the pre-intermediate level, and Book 4 set for the upper-intermediate level (grammatical intricacy score was 1.7 for both levels). Overall, intricacy values in 24 texts in four books ranged from the minimum of 1.2 to the maximum of 2.58 , which are considered the typical intricacy score of written language. The reason for the low intricacy score at the lowest level of book was that texts in Book 1 employed more simple clause complexes in comparison with the other books, while the number of words for all texts were relatively similar. As such, there were a higher number of simple clauses and a higher number of clause complexes, giving lower intricacy values. Texts in the other three books used higher number of ranking clauses which are connected by logico-semantic types in a clause complex, giving higher grammatical intricacy value given that intricacy is measured by the ratio of ranking clauses per clause complex. An extract in Text E2 of Book 1 in Box 2, and another one in Text U1 of Book 4 in Box 3 give an illustration for what has been explained.

Box 2. Illustration of grammatical intricacy in an elementary text

||Dolphins use a whistle-like sound to communicate. ||| $(\alpha)$ Scientists think $\|(' \beta)$ that every dolphin has its own whistle. I||This is like the animal's name, or signature. IIIA dolphin might make this sound to greet others. ||| It may also whistle loudly to signal for help. III Whales also use whistles and 'song' to communicate with other whales. |||Some of these songs can travel thousands of miles through the water. ||| (Extracted from Text E2) 
Box 3. Illustration of grammatical intricacy in an upper-intermediate text

||| (1) Laughter: A scientific Investigation builds on this work in that it assumes animal origins of laughter, $\|(+2)$ and follows van Hooff's distinction between the laugh and the smile. ||| (1) The two expressions are often mentioned in the same breath $\|(+2)$ yet they are used quite differently in primate displays, with the smile expressing affection and appeasement rather than playfulness. ||| (Extracted in Text U1)

As seen in Box 2, there are eight ranking clauses, and seven clause complexes, giving the intricacy of this extract at 1.1. As observed, six out of eight ranking clauses functioned as simple clause complexes. There is only one clause complex consisting of two ranking clauses connected by the hypotactic taxis and logico-semantic type of idea projection (e.g., scientists think that...). Therefore, the intricacy score of this paragraph is really low. Extract in Text U1 in Box 3, on the contrary, displays a higher intricacy scores (two ranking clauses per clause complex). Two ranking clauses in each clause complex in this extract were connected by paratactic taxis and logico-semantic types of extensive expansion (e.g., and, yet).

\section{Conclusion}

This paper reported findings on grammatical intricacy in a selected English textbook series used in TEFL in the tertiary educational Vietnamese context. It started by outlining the context of the research and the research theoretical background. Following that, it described the methodology of the research with a focus on texts and textbooks selection, analytical method and sample analysis. Finally, the findings and discussion were presented, together with the concluding comments. Although the results showed that the complexity of reading texts in the selected book matched the textbook levels and the learners' proficiency from low to high, the upper-intermediate book did not demonstrate the highest use of clause complexes. This indicated that while clause complexes were used at a higher level, the use of simple clauses at the intermediate and upper-intermediate levels can involve other linguistic features that characterise the text complexity. Therefore, further research on other language features such as lexical density, nominalisation and grammatical metaphor (Halliday, 1985a, 1985b) can be done to explore the concept of linguistic complexity in written language in greater depth. Regardless, the present study offers useful insights into one important aspect of linguistic complexity in EFL textbooks and can be a reference for future studies in this area.

\section{References}

Anderson, N. J. (2003a). Active skills for reading, Book 1. Massachusetts: Thomson.

Anderson, N. J. (2003b). Active skills for reading, Book 2. Massachusetts: Thomson.

Anderson, N. J. (2003c). Active skills for reading, Book 3. Massachusetts: Thomson.

Anderson, N. J. (2003d). Active skills for reading, Book 4. Massachusetts: Thomson. 
Benedikt, S., \& Bernd, K. (2009). Between simplification and complexification: non-standard varieties of English around the world. In G. Sampson, D. Gil, \& P. Trudgill (Eds.), Language Complexity as an Evolving Variable (pp. 64-79). New York: Oxford University Press.

Butt, D., Rhondda, F., Sue, S., \& Collin, Y. (2000). Using functional grammar: An explorer's guide. Sydney: National centre for English language teaching and research.

Castello, E. (2008). Text complexity and reading comprehension tests. Bern: Peter Lang.

Dahl, Ö. (2008). Grammatical resources and linguistic complexity: Siriono as a language without NP coordination. In M. Matti, S. Kaius, \& K. Fred (Eds.), Language Complexity: Typology, Contact, Change (pp. 153-164). Amsterdam: John Benjamins.

Eggins, S. (1994). An introduction to systemic functional linguistics. London: Pinter.

Fred, K. (2009). Origin and maintenance of clausal embedded complexity. In G. Sampson, D. Gil \& P. Trudgill (Eds.), Language Complexity as an Evolving Variable (pp. 192-202). New York: Oxford University Press.

Halliday, M. A. K. (1985a). An introduction to functional grammar. London: Arnold.

Halliday, M. A. K. (1985b). Spoken and written language. Deakin: Deakin University.

Halliday, M. A. K. (1994). An introduction to functional grammar (2nd ed.). London: Arnold.

Halliday, M. A. K. (2008). Complementarities in language. Beijing: The Commercial Press.

Halliday, M. A. K., \& Matthiessen, C. M. I. M. (2004). An introduction to functional grammar (3rd ed.). London: Arnold.

Hendrikse, R., \& Van Zweel, H. ( 2010). A phylogenetic and cognitive perspective on linguistic complexity. Southern African Linguistics \& Applied Language Studies, 28(4), 409-422. doi: 10.2989/16073614.2010.548017

Kuiken, F., \& Vedder, I. (2007). Task Complexity and Measures of Linguistic Performance in L2 Writing. International Review of Applied Linguistics in Language Teaching (IRAL), 45(3), 261-284. doi: 10.1515/iral.2007.012

Humphrey, S., Droga, L., \& Feez, S. (2012). Grammar and meaning (new ed.). Newtown, NSW: Primary English Teaching Association Australia.

Lukin, A. (2013). Embedded Clause: A guide for the confused but conscientious. Sydney: Macquarie University.

Martin, J. R. (2001). Language, register and genre. In A. Burns, \& C. Coffin (Eds.), Analysing English in a global context: A reader (pp. 149-166). London: Routlege.

Martin, J. R., \& Rose, D. (2003). Working with discourse: Meaning beyond the clause. London: Continuum.

Miestamo, M. (2008). Grammatical complexity in a cross-linguistic perspective. In M. Matti, 


\section{Macrothink}

S. Kaius, \& K. Fred (Eds.), Language Complexity: Typology, Contact, Change (pp. 23-42). Amsterdam: John Benjamins

Ortega, L. ( 2003). Syntactic complexity measures and their relationship to L2 proficiency: A research synthesis of college-level L2 writing. Applied Linguistics, 24, 492-518.

Patrick, J. (2008). Assessing linguistic complexity. In M. Matti, S. Kaius, \& K. Fred (Eds.), Language Complexity: Typology, Contact, Change (pp. 89-108). Amsterdam: John Benjamins.

Szmrecsanyi, B., \& Kortmann, B. (2012). Introduction: Linguistic complexity Second Language, Acquisition, indigenization, contact. Berlin: De Gruyter.

Thompson, G. (1996). Introducing functional grammar. London: Arnold.

To, V., Fan, S., \& Lê, Q. (2015). Different perspectives on linguistic complexity. In S. Fan., T. Lê \& Q. Lê (Eds), Linguistics and language education in horizons: The link between theory, research and pedagogy (pp. 113-128). New York: Nova Science Publishers.

\section{Appendix}

Raw data of the analysis of grammatical intricacy

\begin{tabular}{|c|c|c|c|c|}
\hline $\begin{array}{c}\text { Coded } \\
\text { texts }\end{array}$ & $\begin{array}{c}\text { Total } \\
\text { words }\end{array}$ & Ranking clauses & Clause complexes & $\begin{array}{c}\text { Grammatical } \\
\text { intricacy }\end{array}$ \\
\hline E1 & 256 & 28 & 22 & 1.27 \\
\hline E2 & 255 & 34 & 22 & 1.55 \\
\hline E3 & 258 & 35 & 19 & 1.84 \\
\hline E4 & 260 & 24 & 20 & 1.20 \\
\hline E5 & 257 & 33 & 18 & 1.83 \\
\hline E6 & 253 & 32 & 18 & 1.78 \\
\hline P1 & 256 & 27 & 17 & 1.59 \\
\hline P2 & 266 & 31 & 12 & 2.58 \\
\hline P3 & 254 & 23 & 14 & 1.64 \\
\hline P4 & 250 & 26 & 16 & 1.63 \\
\hline P5 & 263 & 26 & 17 & 1.53 \\
\hline P6 & 259 & 25 & 16 & 1.56 \\
\hline I1 & 271 & 25 & 14 & 1.79 \\
\hline I2 & 272 & 27 & 14 & 1.93 \\
\hline I3 & 257 & 24 & 12 & 2.00 \\
\hline I4 & 271 & 21 & 16 & 1.31 \\
\hline I5 & 270 & 29 & 14 & 2.07 \\
\hline I6 & 256 & 22 & 13 & 1.69 \\
\hline U1 & 267 & 23 & 14 & 1.64 \\
\hline
\end{tabular}




\begin{tabular}{|c|c|c|c|c|}
\hline $\begin{array}{c}\text { Coded } \\
\text { texts }\end{array}$ & $\begin{array}{c}\text { Total } \\
\text { words }\end{array}$ & Ranking clauses & Clause complexes & $\begin{array}{c}\text { Grammatical } \\
\text { intricacy }\end{array}$ \\
\hline U2 & 266 & 32 & 16 & 2.00 \\
\hline U3 & 274 & 25 & 15 & 1.67 \\
\hline U4 & 267 & 22 & 17 & 1.29 \\
\hline U5 & 260 & 27 & 13 & 2.08 \\
\hline U6 & 265 & 25 & 15 & 1.67 \\
\hline
\end{tabular}

\section{Copyright Disclaimer}

Copyright for this article is retained by the author(s), with first publication rights granted to the journal.

This is an open-access article distributed under the terms and conditions of the Creative Commons Attribution license (http://creativecommons.org/licenses/by/3.0/). 